Prepared in cooperation with the Air Force Civil Engineer Center

\title{
Depth to Bedrock Based on Modeling of Gravity Data of the Eastern Part of Edwards Air Force Base, California
}
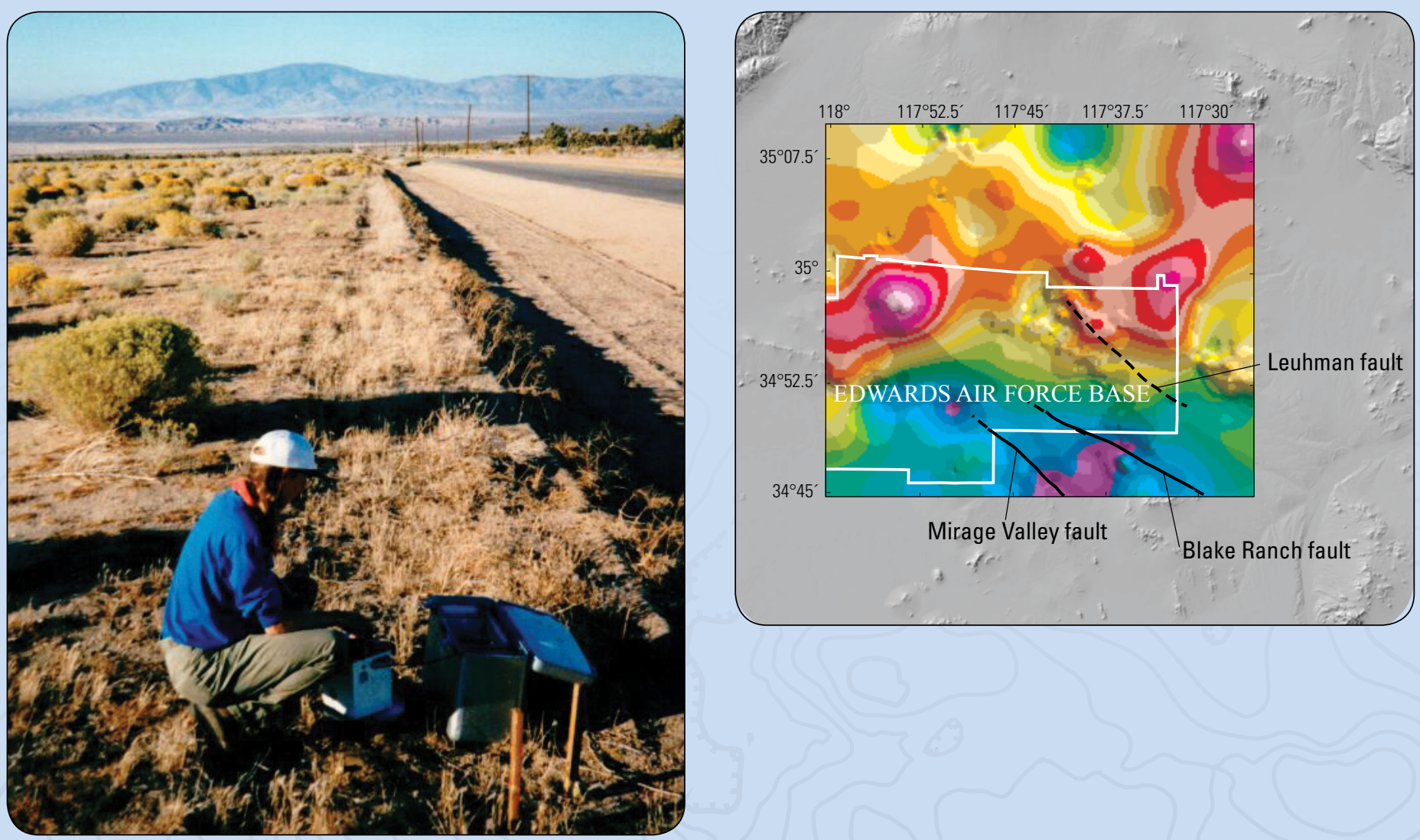

Open-File Report 2019-1128 
Cover. U.S. Geological Survey (USGS) photograph of USGS scientist (Victoria Langenheim) making gravity measurements southwest of Edwards Air Force Base. Bedrock gravity map (right) of Edwards Air Force Base and surrounding area overlying 3DEP Elevation hillshade map. Base from U.S.

Geological Survey The National Map. 


\section{Depth to Bedrock Based on Modeling of Gravity Data of the Eastern Part of Edwards Air Force Base, California}

By Victoria E. Langenheim, Andrew Morita, Allen H. Christensen, Geoffrey Cromwell, and Christopher Ely

Prepared in cooperation with the Air Force Civil Engineer Center

Open-File Report 2019-1128 


\title{
U.S. Department of the Interior \\ DAVID L. BERNHARDT, Secretary
}

\author{
U.S. Geological Survey \\ James F. Reilly II, Director
}

U.S. Geological Survey, Reston, Virginia: 2019

For more information on the USGS - the Federal source for science about the Earth, its natural and living resources, natural hazards, and the environment—visit https://www.usgs.gov or call 1-888-ASK-USGS.

For an overview of USGS information products, including maps, imagery, and publications, visit https://store.usgs.gov/.

Any use of trade, firm, or product names is for descriptive purposes only and does not imply endorsement by the U.S. Government.

Although this information product, for the most part, is in the public domain, it also may contain copyrighted materials as noted in the text. Permission to reproduce copyrighted items must be secured from the copyright owner.

Suggested citation:

Langenheim, V.E., Morita, A., Christensen, A.H., Cromwell, G., and Ely, C., 2019, Depth to bedrock based on modeling of gravity data of the eastern part of Edwards Air Force Base, California: U.S. Geological Survey Open-File Report 2019-1128, 12 p., https://doi.org/10.3133/ofr20191128.

ISSN 2331-1258 (online) 


\section{Contents}

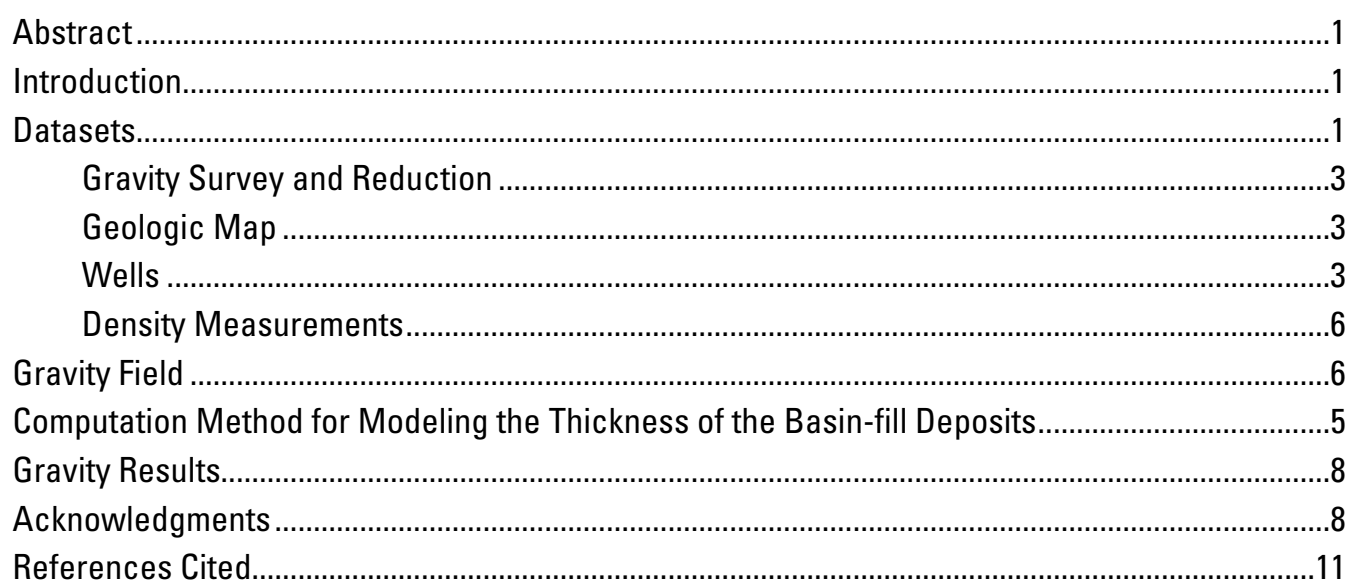

\section{Figures}

1. Simplified geologic map of the eastern part of Edwards Air Force Base ..........................2

2. Shaded-relief isostatic gravity map of study area, illumination from the east. ................4

3. Shaded-relief topographic map showing isostatic gravity contours ................................5

4. Map showing the thickness of the basin-fill deposits computed from gravity measurements in the eastern part of Edwards Air Force Base and well constraints ......9

5. Bedrock gravity map of study area. .............................................................................

\section{Tables}

1. Density measurements of hand samples............................................................................

2. Assumed density contrast with depth in the study area .................................................8 


\title{
Conversion Factors
}

International System of Units to U.S. customary units

\begin{tabular}{lcl}
\hline \multicolumn{1}{c}{ Multiply } & By & \multicolumn{1}{c}{ To obtain } \\
\hline meter $(\mathrm{m})$ & Length & \\
kilometer $(\mathrm{km})$ & 3.281 & foot $(\mathrm{ft})$ \\
& 0.6214 & mile $(\mathrm{mi})$ \\
\hline square kilometer $\left(\mathrm{km}^{2}\right)$ & Area & \\
square kilometer $\left(\mathrm{km}^{2}\right)$ & 247.1 & acre \\
\hline & 0.3861 & square mile $\left(\mathrm{mi}^{2}\right)$ \\
\hline gram $(\mathrm{g})$ & Mass & \\
kilogram $(\mathrm{kg})$ & 0.03527 & ounce, avoirdupois $(\mathrm{oz})$ \\
\hline & 2.205 & pound avoirdupois $(\mathrm{lb})$ \\
\hline kilogram per cubic meter $\left(\mathrm{kg} / \mathrm{m}^{3}\right)$ & Density & \\
gram per cubic centimeter $\left(\mathrm{g} / \mathrm{cm}^{3}\right)$ & 0.06242 & pound per cubic foot $\left(\mathrm{lb} / \mathrm{ft}^{3}\right)$ \\
\hline
\end{tabular}

\section{Datum}

Vertical coordinate information is referenced to the National Geodetic Vertical Datum of 1929 (NGVD29).

Horizontal coordinate information is referenced to the North American Datum of 1927 (NAD27).

Altitude, as used in this report, refers to distance above the vertical datum.

\section{Abbreviations}

\author{
BRF Blake Ranch fault \\ EAFB Edwards Air Force Base \\ GPS Global Positioning System \\ KHF Kramer Hills fault \\ LF Leuhman fault \\ MVF Mirage Valley fault \\ OPUS Online Positioning User Service \\ RTK Real-Time Kinematic \\ SF Spring fault
}





\title{
Depth to Bedrock Based on Modeling of Gravity Data of the Eastern Part of Edwards Air Force Base, California
}

\author{
By Victoria E. Langenheim, Andrew Morita, Allen H. Christensen, Geoffrey Cromwell, and Christopher Ely
}

\begin{abstract}
We describe a gravity survey acquired to determine the thickness of basin-fill deposits (depth to bedrock) and to delineate geologic structures that might influence groundwater flow beneath the eastern part of Edwards Air Force Base, California. Inversion of these gravity data combined with geologic map and well information provides an estimate of the thickness of basin-fill deposits (defined here as Cenozoic sedimentary and volcanic rocks). After removing the gravitational effect of the basin-fill deposits, the inversion also results in a gravity map that reflects variations in the bedrock density. The depth to bedrock is generally less than 1 kilometer in the map area, except for localized depressions north and south of Kramer Hills, northwest-trending pockets about 4 kilometers northeast of Rogers Lake, and a large depression southwest of Rogers Lake. In the area near Leuhman Ridge, depth to bedrock is shallow. The Spring and Leuhman faults do not coincide with large variations in basin-fill thickness or with prominent gravity gradients, suggestive of minor vertical displacement and minor horizontal displacement at their southeastern mapped extents where they project across a large gravity low.
\end{abstract}

\section{Introduction}

Depth to bedrock is an important constraint for modeling groundwater volume and flow. In the arid Mojave Desert, communities and military installations depend on groundwater for their source of water. In parts of the western Mojave Desert, groundwater withdrawal has led to land subsidence and fissuring, adversely affecting landing of airplanes and space shuttles on Rogers Lake at Edwards Air Force Base (EAFB; Londquist and others, 1993). This study is motivated by the need for better understanding of the groundwater resources, alluvial fill, and the geometry of the underlying bedrock for EAFB and nearby communities.
The gravity method, measuring the variation of earth's gravitational field at specific locations, has been used to estimate the thickness of basin-fill deposits of the Mojave Desert for many decades, starting with a regional gravity study by Mabey (1960). This method takes advantage of the large density contrast between Cenozoic sedimentary and volcanic units (hereafter referred to as basin-fill deposits) and the underlying dense pre-Cenozoic bedrock. Previously, detailed gravity surveys were acquired in the western part of EAFB to determine depth to bedrock, particularly near Graham Ranch and the eastern edge of Rogers Lake (fig. 1; Morin and others, 1990). For this study gravity data were acquired to determine the thickness of the basin-fill deposits, bedrock geometry, and to delineate geologic structures that might influence groundwater flow beneath the eastern part of EAFB (fig. 1).

\section{Datasets}

Primary datasets used to determine the thickness of basin-fill deposits were gravity measurements, geologic map information, and drillers' logs of water wells. Aeromagnetic data (Roberts and Jachens, 1999) were useful for delineating the main fault strand of the Mirage Valley fault and its cumulative offset (see Jachens and others, 2002) but not particularly useful for determining the thickness of basin fill or detailed enough to clearly delineate the displacement on individual strands of the Mirage Valley and other faults in the study area. The basin-fill deposits (QTs and Tv in fig. 1) consist of locally derived Quaternary and Tertiary sedimentary rocks and sediments (Dibblee, 1960a, 1960b, 1967) in addition to Tertiary volcanic rocks. Basin-fill deposits overlie crystalline basement complex rocks (bedrock) that are predominantly Mesozoic granitic rocks (fig. 1) with isolated screens and pendants of metasedimentary rock and hornblende schist (Dibblee, 1960a, 1960b, 1967). Granitic bedrock (particularly quartz monzonite) weathers to form coarse residual sand (grus), which can grade into alluvial sands on lower slopes (Dibblee, 1960b), making recognition of the contact between bedrock and basinfill deposits locally challenging. 

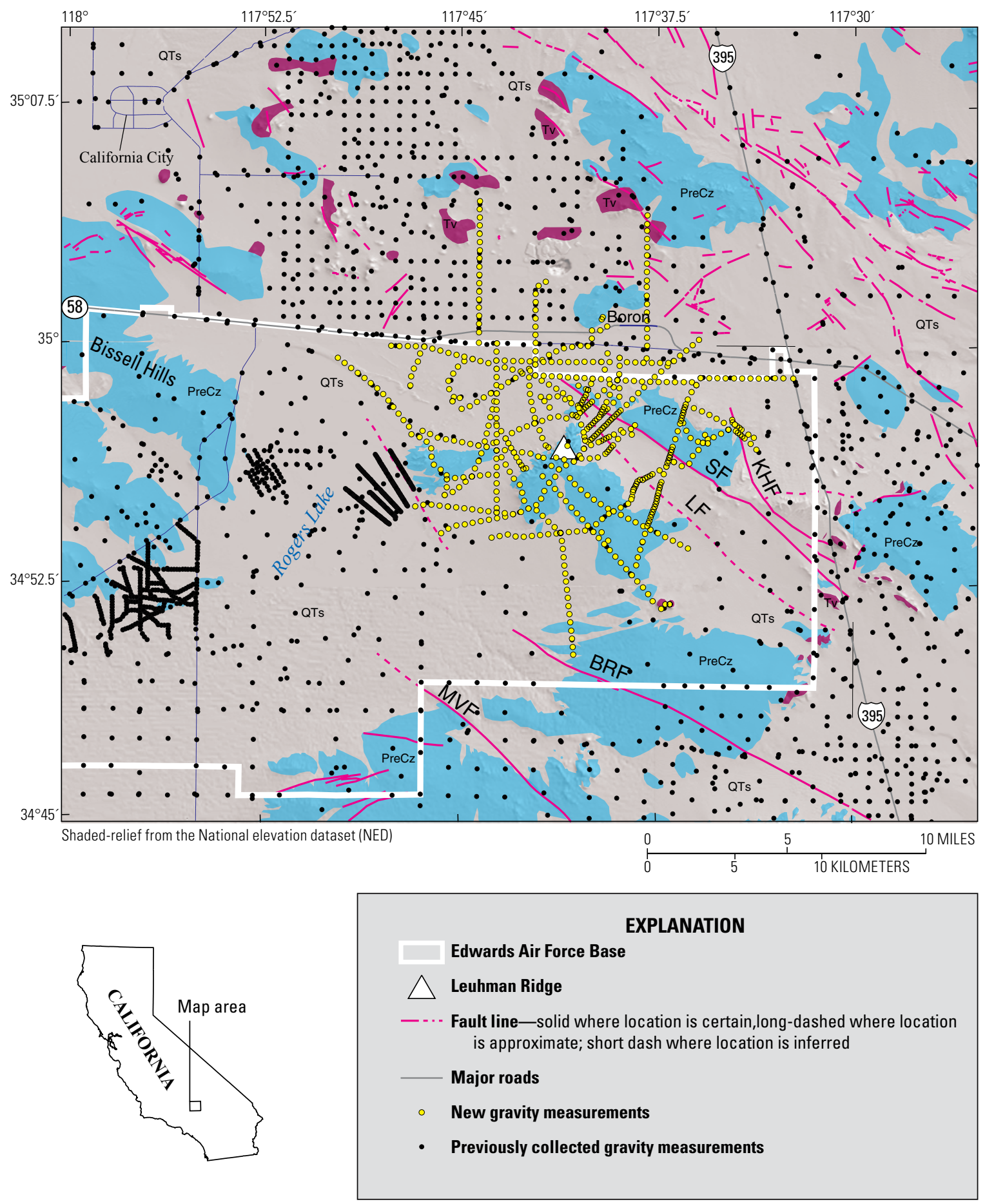

Figure 1. Simplified geologic map of the eastern part of Edwards Air Force Base (EAFB; heavy white line). Map is modified from Dibblee (1960a, 1960b, 1967). Rock unit abbreviations: PreCz, pre-Cenozoic bedrock; Tv, Tertiary volcanic rocks; QTs, Quaternary and Tertiary sedimentary deposits. Yellow dots show new gravity measurements; black dots show previously collected gravity measurements (Morin and others, 1990; Subsurface Surveys, 1990; Pan-American Center for Earth and Environmental Studies, 2010); magenta lines show faults (Dibblee, 1960a, 1960b; Miller and others, 2007). Abbreviations for selected faults in EAFB: BRF, Blake Ranch fault; KHF, Kramer Hills fault; LF, Leuhman fault; MVF, Mirage Valley fault, SF, Spring fault. White triangle marks location of Leuhman Ridge. Narrow dark blue lines are local roadways. 


\section{Gravity Survey and Reduction}

In 2015-2017 we collected 671 new gravity measurements in or near the northeast part of EAFB using a LaCoste Romberg Model D-79 with Aliod 100 gravity meter. Measurements were spaced about 485 meters (m;1590 feet [ft]) apart, except for selected profiles that cross the Kramer Hills, Leuhman, and Spring faults, where spacing is $160 \mathrm{~m}$ $(530 \mathrm{ft}$ ) to provide more detail. The location and elevation of each gravity measurement was determined using a Trimble Real-Time Kinematic (RTK) R7 and R8 Global Positioning System (GPS) base and rover receivers. This system is capable of obtaining vertical and horizontal coordinates with a precision of $0.025 \mathrm{~m}(0.083 \mathrm{ft})$ between rover and base by using traditional RTK methods described by Morton and others (1993). The RTK survey was referenced to the North American Vertical Datum of 1988 (NAVD 88) by using local bench marks and surveyed locations using methods described by Rydlund and Densmore (2012), and it was processed using National Geodetic Survey Online Positioning User Service (OPUS) software (OPUS-Projects Team, 2017).

New gravity measurements were tied to base station PB1104 (observed gravity value of 979,462.12 milligals [mGal]; Roberts and Jachens, 1986); these measurements supplemented data previously collected at 2,107 sites in the map area of figure 1 (Morin and others, 1990; Subsurface Surveys, 1990; Pan-American Center for Earth and Environmental Studies, 2010). Gravity data were reduced using the Geodetic Reference System of 1967 (International Union of Geodesy and Geophysics, 1971) and referenced to the International Gravity Standardization Net 1971 gravity datum (Morelli, 1974, p. 18). Gravity data were reduced to isostatic anomalies using a reduction density of 2,670 kilograms per cubic meter $\left(\mathrm{kg} / \mathrm{m}^{3}\right)$ and include earth-tide, instrument drift, free-air, Bouguer, latitude, curvature, and terrain corrections (Telford and others, 1990). An isostatic correction, using a sealevel crustal thickness of 25 kilometers $(\mathrm{km} ; 16$ miles [mi]) and a mantle-crust density contrast of $400 \mathrm{~kg} / \mathrm{m}^{3}$, was applied to the gravity data (see accompanying file gravity_data.csv) to remove the long-wavelength gravitational effect of crustal isostatic compensation due to topographic loading. The data were gridded at a spacing of $250 \mathrm{~m}(820 \mathrm{ft})$, roughly the spacing of gravity stations along the detailed profiles, using a minimum curvature algorithm (Briggs, 1974). The resulting gravity field, termed the isostatic residual gravity anomaly, is shown in figures 2 and 3.
Terrain corrections were calculated to a radial distance of $167 \mathrm{~km}$ (104 mi) and involved a 3-part process: (1) HayfordBowie zones A and B with an outer radius of $68 \mathrm{~m} \mathrm{(223 \textrm {ft } )}$ were estimated in the field with the aid of tables and charts, (2) Hayford-Bowie zones $\mathrm{C}$ to $\mathrm{M}$ with an outer radius of 2,000 $\mathrm{m}(6,562 \mathrm{ft})$ were calculated using a $30-\mathrm{m}(100-\mathrm{ft})$ digital elevation model, and (3) terrain corrections from a distance of $2.0 \mathrm{~km}(6,562 \mathrm{ft})$ to $167 \mathrm{~km}(104 \mathrm{mi})$ were calculated using a digital elevation model and a procedure proposed by Plouff (1977). Total terrain corrections for the stations collected for this study ranged from 0.02 to $5.05 \mathrm{mGal}$, averaging 0.25 $\mathrm{mGal}$. If the error resulting from the terrain correction is considered to be 5 to 10 percent of the total terrain correction, the largest error from the terrain correction expected for the data is $0.5 \mathrm{mGal}$; however, the average error resulting from the terrain corrections is small (less than $0.03 \mathrm{mGal}$ ) for most of the stations due to low topographic relief. For comparison, isostatic residual gravity values, including the older measurements in the study area, ranged from about -43 to $-4 \mathrm{mGal}$.

\section{Geologic Map}

Various geologic maps (Dibblee, 1960a; plate 2 of Dibblee, 1960b; plate 1 of Dibblee, 1967; Miller and others, 2007) were used for this gravity study. These geologic data were used primarily to delineate the Cenozoic basin-fill deposits from the basement complex and to compare the locations of mapped and inferred faults with those defined by gravity and aeromagnetic data.

\section{Wells}

More than 100 wells (data planned to be released; Cromwell and others, in press) penetrated bedrock within the study area (fig. 3). These wells helped constrain the gravity interpretations. We note the inherent uncertainty in picking the depth at which the well encountered competent bedrock from the logs due to (1) the absence of retrieved samples to examine, (2) descriptions by drillers who are not geologists, and (3) the significant weathering of the granitic bedrock (up to $15 \mathrm{~m}$ [50 ft] in other places in the Mojave Desert according to Powell and Matti, 2000). In addition, 146 wells that did not penetrate bedrock (Cromwell and others, in press) were compared to the depth to bedrock predicted from the gravity model (see accompanying file basin_wells.csv). 

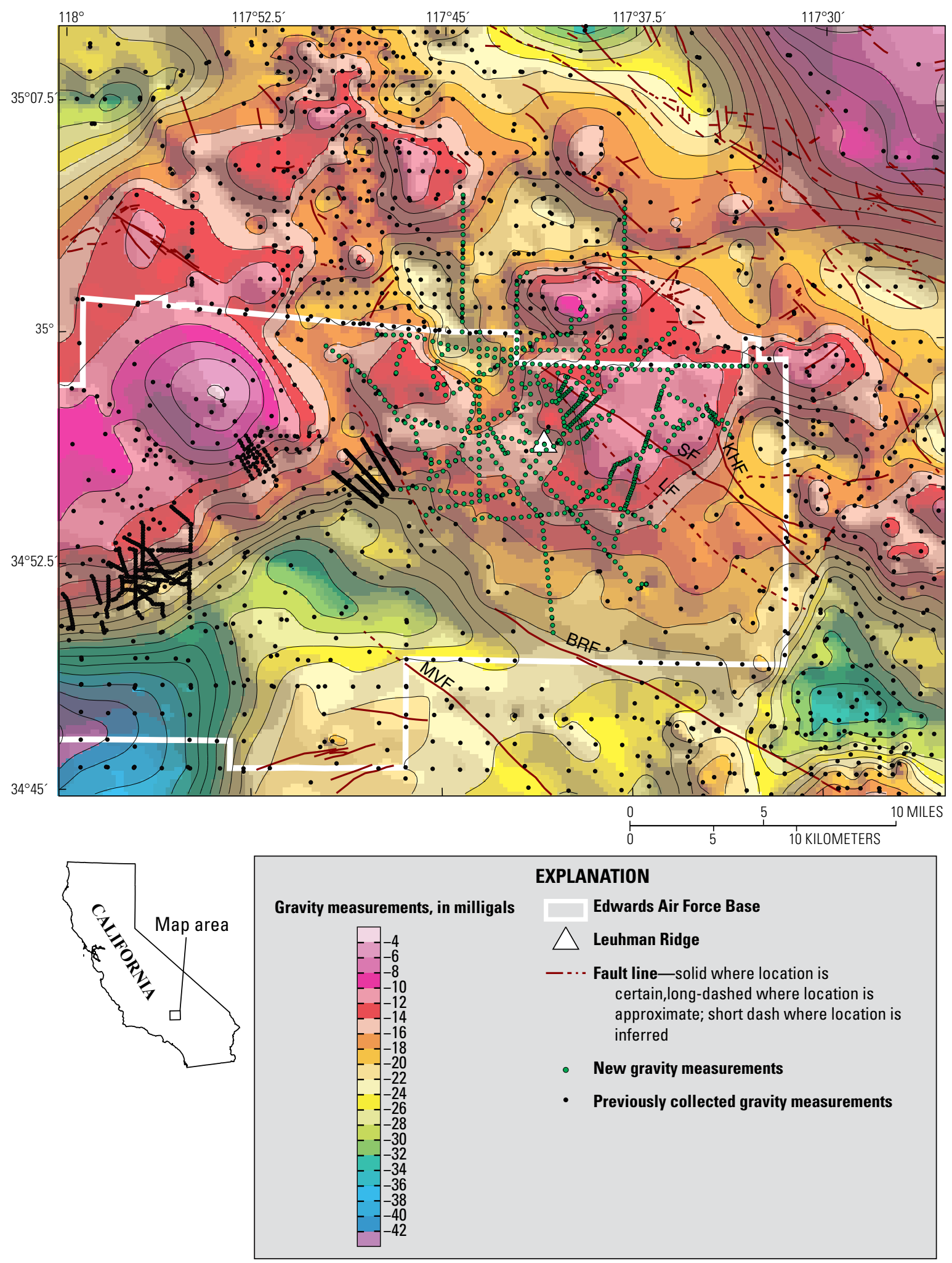

Figure 2. Shaded-relief isostatic gravity map of study area, illumination from the east. Brown lines show faults from Dibblee (1960a, 1960b) and Miller and others (2007). Abbreviations of selected faults: BRF, Blake Ranch fault; KHF, Kramer Hills fault; LF, Leuhman fault; MVF, Mirage Valley fault; SF, Spring fault. Green dots show new gravity measurements; black dots show previously collected gravity measurements (Morin and others, 1990; Subsurface Surveys, 1990; Pan-American Center for Earth and Environmental Studies, 2010). White triangle marks location of Leuhman Ridge. Contour interval is $2 \mathrm{mGal}$. 

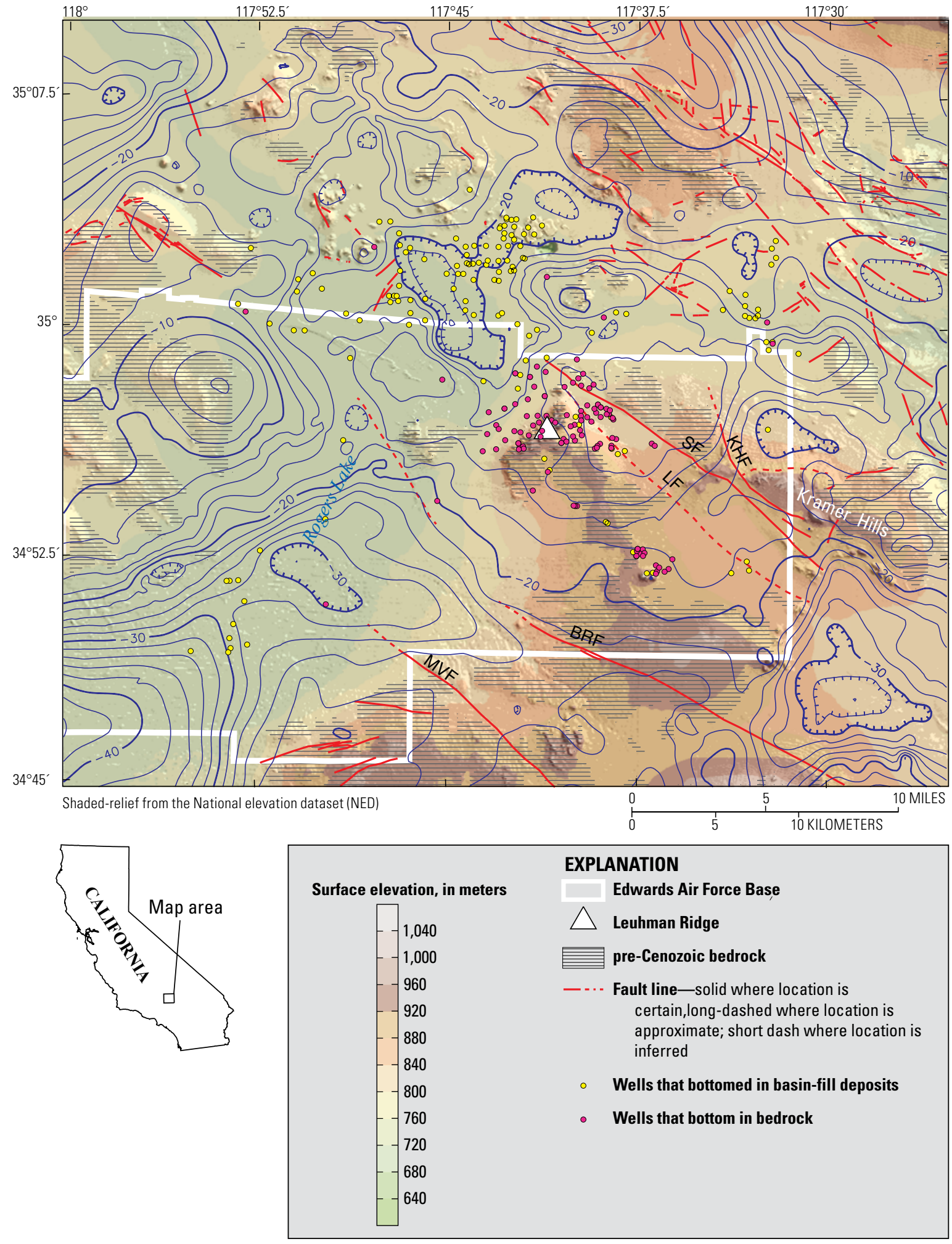

Figure 3. Shaded-relief topographic map showing isostatic gravity contours (blue lines) from figure 2. Gray striped areas show pre-Cenozoic bedrock. Red lines show faults from Dibblee (1960a, 1960b) and Miller and others (2007). Abbreviations of selected faults: BRF, Blake Ranch fault; KHF, Kramer Hills fault; LF, Leuhman fault; MVF, Mirage Valley fault; SF, Spring fault. Yellow dots show wells that bottomed in basin-fill deposits; magenta dots show wells that bottom in bedrock. White triangle marks location of Leuhman Ridge. Contour interval is $2 \mathrm{mGal}$. 
Depth to Bedrock Based on Modeling of Gravity Data, Edwards Air Force Base, California

\section{Density Measurements}

Measurements were made on 38 hand samples of bedrock in the study area (table 1). Densities were determined using a precision Sartorius electronic balance with a precision of 0.01 gram. All rocks were weighed dry in air (Wa) and saturated in water $(\mathrm{Ww})$. From these measurements grain density was calculated using the following formula:

$$
\text { Grain density }=[\mathrm{Wa} /(\mathrm{Wa}-\mathrm{Ww})]^{*} 1000
$$

Densities varied from 2,560 to $2,790 \mathrm{~kg} / \mathrm{m}^{3}$. The average density was $2636 \pm 46 \mathrm{~kg} / \mathrm{m}^{3}$ (1 sigma standard deviation). The highest densities were measured in the central and west central parts of the study area, generally consistent with the gravity anomaly pattern in fig. 2 . The lowest densities do not correlate as well with gravity lows.

\section{Gravity Field}

The gravity field of the study area (here expressed as the isostatic residual gravity field; fig. 2) is complex, and it reflects both the large density contrast between denser rocks of the bedrock and the less dense Cenozoic basin-fill deposits, as well as substantial density variations within the bedrock (gray striped areas in fig. 3). Gravity values measured on bedrock exposures vary from $-4 \mathrm{mGal}$ in the west central part of the study area to $-26 \mathrm{mGal}$ along the southern edge of the study area. The gravity field has a northwest grain (highlighted by shaded relief in fig. 2) that is parallel to mapped faults, particularly in the eastern half of the map area. Pronounced northeast-striking gradients interrupt the northwest grain, most notably $10 \mathrm{~km}$ west of Leuhman Ridge. The northeast-striking gravity gradient is associated with resistivity anomalies, subtle surface escarpments, and an alignment of historical springs, indicating a structural boundary (Dixon and others, 1994). This structural boundary borders the most significant gravity low in the southwest corner of the study area and forms the northeast edge of a deep basin (Jachens and others, 2014). Many of the new gravity measurements define a large, broad gravity high (values greater than $-24 \mathrm{mGal}$ ) coincident with outcrops of quartz monzonite. The Leuhman and Spring faults cross this high without producing significant, linear gravity gradients, suggesting that these faults have minor vertical and horizontal displacement, at least within the extent of the gravity high. A slight gravity 'ridge' (linear configuration of higher values) lies between the northwestern parts of the two faults where they converge. The ridge projects a couple of kilometers beyond the fault traces where it transitions into a northwest-trending, 10-km-long gravity low. This low could reflect a strike-slip basin, but mapped faults that would define an extensional stepover in this region are not apparent. Alternatively, this gravity low may reflect a basin that formed during early Miocene extension, such as the gravity low north of the Kramer Hills (fig. 3). A deep drill hole in the gravity low $(1,067 \mathrm{~m}[3,500 \mathrm{ft}])$ bottomed in Miocene sedimentary deposits similar to those exposed in the Kramer Hills (Dibblee, 1960b).

\section{Computation Method for Modeling the Thickness of the Basin-fill Deposits}

The thickness of the basin-fill deposits (or depth to bedrock) throughout the study area was estimated by the method of Jachens and Moring (1990), modified slightly to permit inclusion of constraints at points where the thickness (or minimum thickness) of the basin-fill deposits is known from direct observations in drill holes. An initial estimate of the basinfill deposits gravity anomaly is made by passing a smooth surface through the gravity values at stations measured where the bedrock crops out (initial estimate of the bedrock gravity field) and subtracting this surface from the isostatic residual gravity field (fig. 2). This represents only the initial estimate because the gravity values at points on bedrock that lie close to the basin-fill deposits are sensitive to the low-density basinfill deposits, and they have lower gravity values than if the basin-fill deposits were not present. To compensate for this effect, the initial basin-fill deposits' gravity anomaly is used to calculate an initial estimate of basin-fill deposit thickness, and the gravity effect of these basin-fill deposits is calculated at all of the bedrock stations. A second estimate of the bedrock gravity field is then made by passing a smooth surface through the bedrock gravity values corrected by the basin-fill effect, and the process is repeated to produce a second estimate of basinfill deposit thickness. This process is repeated until further steps do not result in significant changes to the modeled thickness of the basin-fill deposits, usually in five or six steps.

The gravity anomaly associated with basin-fill deposits was converted to thickness of the basin-fill deposits using an assumed density increase of the basin deposits with depth. This density increase can be expressed as change in density contrast with underlying bedrock (table 2). This density-depth relation was derived for the western Mojave Desert (Jachens and others, 2014) by converting sonic velocity measured in well logs of basin fill to density using the relation of Gardner and others (1974). Using the relation in table 1 of Brocher (2005) or the relation developed for the Basin and Range province (Jachens and Moring, 1990), the density contrasts would be greater than assumed here for the western Mojave Desert, leading to thinner computed basin fill. The reasonableness of this selected density contrast, at least for the western Mojave Desert region, was further tested by examining the bedrock gravity field for any indications of local anomalies at the sites where wells penetrated bedrock, and the solution was constrained to honor those data. Note that a 10 percent decrease in the density contrast produces an average 20 percent increase in basin thickness for the study area. 
Table 1. Density measurements of hand samples.

$\left[\mathrm{kg} / \mathrm{m}^{3}\right.$, kilogram per cubic meter]

\begin{tabular}{|c|c|c|c|c|}
\hline Name & Latitude & Longitude & $\begin{array}{c}\text { Grain density } \\
\left(\mathbf{k g} / \mathbf{m}^{3}\right)\end{array}$ & Rock type \\
\hline RCJ58-8 & -117.9028 & 34.9440 & 2,700 & granite \\
\hline RCJHV1 & -117.8600 & 34.7540 & 2,610 & granite \\
\hline RCJ58-7 & -117.7558 & 34.9198 & 2,660 & granite \\
\hline RCJ58-6 & -117.7000 & 34.9107 & 2,560 & granite \\
\hline PB1011 & -117.5695 & 35.0770 & 2.590 & granite \\
\hline DR330 & -117.7757 & 34.7702 & 2.690 & granodiorite \\
\hline DR329 & -117.7213 & 34.7977 & 2,670 & granodiorite \\
\hline MMM52-7 & -117.866 & 34.7722 & 2,680 & granodiorite \\
\hline NOVWAX01 & -117.679 & 34.9585 & 2,630 & granodiorite \\
\hline NOVWAX02 & -117.6743 & 34.9632 & 2,740 & quartz diorite \\
\hline 89Е044 & -117.9377 & 34.8607 & 2,610 & quartz monzonite \\
\hline 89Е059 & -117.7853 & 34.9473 & 2,620 & granite \\
\hline 89E091 & -117.704 & 34.9077 & 2,600 & quartz monzonite \\
\hline 89Е035 & -117.964 & 34.9113 & 2,610 & quartz monzonite \\
\hline 89Е029 & -117.994 & 34.9382 & 2,590 & aplite dike \\
\hline 89E031 & -117.9832 & 34.9188 & 2,620 & quartz monzonite \\
\hline 89Е039 & -117.9522 & 34.9938 & 2,590 & quartz monzonite \\
\hline 89E090 & -117.6957 & 34.9365 & 2,620 & quartz monzonite \\
\hline 89Е073 & -117.6412 & 34.8297 & 2,590 & quartz monzonite \\
\hline 89Е085 & -117.656 & 34.925 & 2,690 & granite \\
\hline PB1109 & -117.7467 & 34.8015 & 2,610 & quartz monzonite \\
\hline 89E098 & -117.9945 & 34.8387 & 2,610 & granite \\
\hline 89E264 & -117.6663 & 34.7783 & 2,610 & quartz monzonite \\
\hline 89E244 & -117.7617 & 34.9325 & 2,600 & quartz monzonite \\
\hline $89 \mathrm{E} 283$ & -117.7755 & 34.9238 & 2,630 & quartz monzonite \\
\hline $89 \mathrm{E} 256$ & -117.7377 & 34.8077 & 2,650 & quartz monzonite \\
\hline 89E2855 & -117.8215 & 34.7787 & 2,680 & granite \\
\hline 89Е007 & -117.8463 & 34.9433 & 2,790 & granite \\
\hline 89E012 & -117.9130 & 34.9632 & 2,660 & tonalite \\
\hline 89E014 & -117.9415 & 34.9722 & 2,620 & quartz monzonite \\
\hline 89Е089 & -117.6838 & 34.9405 & 2,600 & granite \\
\hline 89Е088 & -117.6812 & 34.9497 & 2,620 & granite \\
\hline $89 \mathrm{E} 289$ & -117.8958 & 34.9623 & 2,680 & tonalite \\
\hline 89Е013 & -117.9315 & 34.9703 & 2,610 & quartz monzonite \\
\hline $89 \mathrm{E} 2625$ & -117.6843 & 34.8007 & 2,600 & quartz monzonite \\
\hline $89 \mathrm{E} 2835$ & -117.8297 & 34.7765 & 2,640 & quartz monzonite \\
\hline 89E2445 & -117.7685 & 34.9305 & 2,650 & granite \\
\hline $89 \mathrm{E} 2855$ & -117.7968 & 34.7867 & 2,660 & quartz diorite \\
\hline
\end{tabular}


Table 2. Assumed density contrast with depth in the study area.

[ft, feet; $\mathrm{m}$, meters; BLS, below land-surface datum; $\mathrm{kg} / \mathrm{m}^{3}$, kilogram per cubic meter; >, greater than]

\begin{tabular}{rrr}
\hline Depth range $\mathbf{f t t} \mathbf{B L S})$ & Depth range $(\mathbf{m}$ BLS) & Density contrast $\left(\mathbf{k g} / \mathbf{m}^{\mathbf{3}}\right)$ \\
\hline-689 & $0-210$ & -530 \\
$689-2,001$ & $210-610$ & -410 \\
$2,001-3,740$ & $610-1,140$ & -290 \\
$>3,740$ & $>1,140$ & -180 \\
\hline
\end{tabular}

\section{Gravity Results}

Results of the gravity inversion are shown in figure 4 as a map of basin-fill deposit thickness or subsurface depth to bedrock and in figure 5 as a bedrock gravity map. Uncertainties in the gravity data mean that the best resolution in basin-fill thickness that can be expected, even in areas of good gravity coverage, is about $\pm 15 \mathrm{~m}(50 \mathrm{ft})$, and resolution is likely less in areas of poor gravity coverage or in areas far from bedrock outcrop. Also, because the calculations were performed on grid cells $250 \mathrm{~m}(820 \mathrm{ft})$ on a side, the results represent averages of basin-fill deposit thickness over this cell size. Thus, variations of basin-fill deposit thickness over distances less than the cell-dimension are not resolved. Finally, gravity data reflect the average shape of the causative body (in this case the thickness of the basin-fill deposits; see, for example, Blakely, 1995) and the averaging becomes more pronounced the farther from the source that the observations are taken. As a result, places where the basin-fill deposits are the thickest will be subject to higher degrees of averaging, and thus will appear smoother than areas where the basin-fill deposits are thinner. Uncertainty also arises from incomplete knowledge of the gravity field that results from density variations in the bedrock. The gravity and bedrock gravity maps (figs. 2 and 5) clearly show gravity values in the southern part of the map area that are 10-20 mGal lower than those measured on bedrock outcrops to the north and west, indicating that bedrock density variations are present in the study area. These variations are taken into account by the inversion, but the field is incompletely known particularly in the southwest part of the study area and north of Rogers Lake (fig. 4) where there are no nearby bedrock outcrops.

Comparison of modeled bedrock depths with depths at which bedrock was reported in logs (see accompanying file basement_wells.csv) indicate that the gravity inversion yielded reasonable results, at least at the location of the water wells. The average difference between predicted and actual bedrock depths at the 114 bedrock wells was $1.2 \pm 6 \mathrm{~m}(4 \pm 19 \mathrm{ft})$, with a maximum difference of $18 \mathrm{~m}(60 \mathrm{ft})$. Another measure of the reliability of the solution can be obtained by comparing the calculated thicknesses with the total well depths that did not encounter bedrock. For most of these wells, the calculated thickness of the basin-fill deposits is greater than the total well depth, as was observed. Where the total well depth exceeds the modeled bedrock depth, wells were either (1) within a grid cell of adjacent wells that encountered bedrock at shallower depths, (2) within a steep gravity gradient, or (3) in an area poorly constrained by nearby gravity measurements. These results also imply that the assumed density-depth relation cannot be any larger because the resulting calculated thickness of the basin-fill deposits would be less than the minimum thickness of deposits at the wells.

Our results are generally consistent with those of Jachens and others (2014), but they provide additional resolution and detail that result from a finer grid cell size, considerably better gravity coverage in the central part of the study area, and additional well constraints. The gravity inversion indicates that the average thickness of basin-fill deposits within the area of figure 4 is $262 \mathrm{~m}(860 \mathrm{ft})$ The thickest, most extensive basin-fill deposits are located in the southwest corner of the map area. Other locally thick (more than 1,219 m or 4,000 ft) deposits are north of the Kramer Hills, about $6 \mathrm{~km}$ northwest of the northwestern-most tips of the Spring and Leuhman faults, and in the northwest and southeast parts of the study area.

In the region between the Spring and Leuhman faults, the depth to bedrock is generally less than $122 \mathrm{~m}$ (400 ft). No large vertical offsets are obvious in the depth to bedrock map in this region, similar to the lack of steep gravity gradients in figure 2. North of Leuhman Ridge, the depth to bedrock is fairly shallow where wells penetrate bedrock. In this area, the bedrock gravity indicates denser bedrock closer to Leuhman Ridge (fig. 5). Although the northern margin of the bedrock gravity high is not constrained tightly by well data north of the Spring fault, some deepening of the bedrock surface north of the base boundary is likely, given the distribution of gravity measurements on bedrock.

\section{Acknowledgments}

The Air Force Civil Engineer Center (AFCEC) provided funding for this study. Darcy McPhee and David Miller provided reviews that improved the report. 

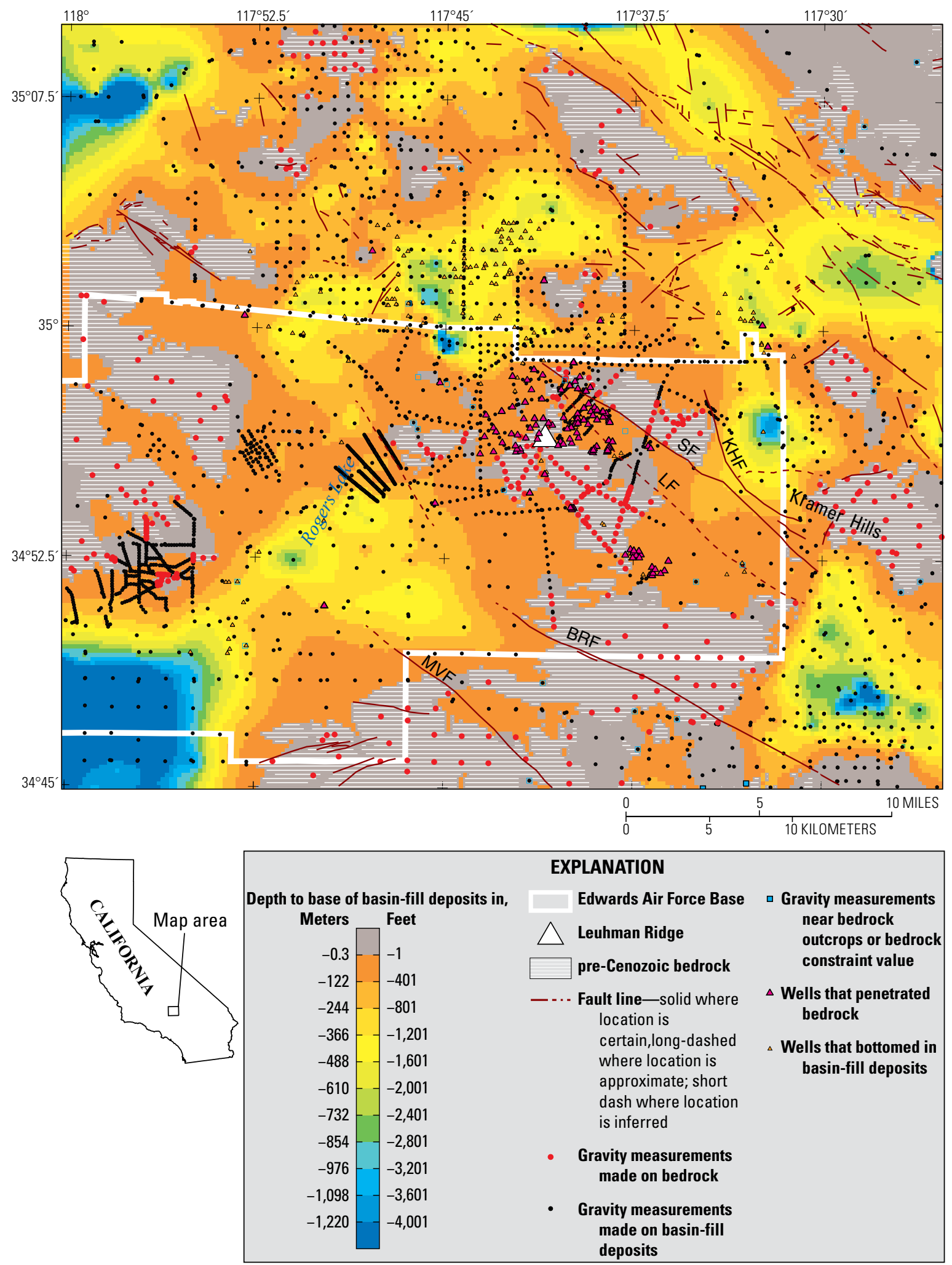

Figure 4. Map showing the thickness of the basin-fill deposits computed from gravity measurements in the eastern part of Edwards Air Force Base and well constraints. White striped areas show pre-Cenozoic bedrock. Brown lines show faults from Dibblee (1960a, 1960b) and Miller and others (2007). Abbreviations of selected faults: BRF, Blake Ranch fault; KHF, Kramer Hills fault; LF, Leuhman fault; MVF, Mirage Valley fault; SF, Spring fault. Red dots show gravity measurements made on bedrock, black dots show gravity measurements made on basin-fill deposits; blue squares show gravity measurements near bedrock outcrops or bedrock constraint value; magenta and yellow triangles indicate wells that penetrated bedrock and bottomed in basin-fill deposits, respectively. 

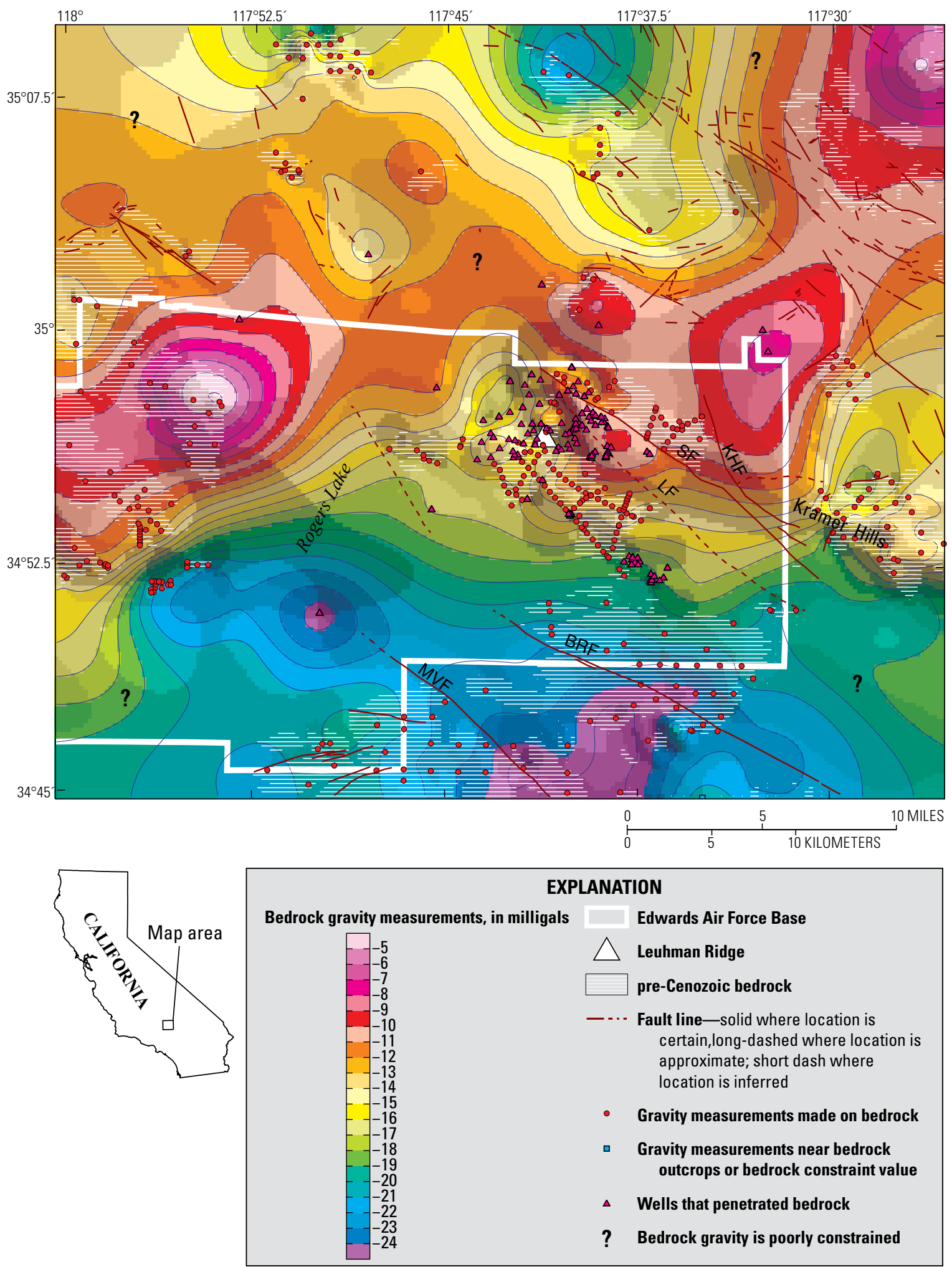

Figure 5. Bedrock gravity map of study area. White striped areas show pre-Cenozoic bedrock. Brown lines show faults from Dibblee (1960a, 1960b) and Miller and others (2007). Abbreviations of selected faults: BRF, Blake Ranch fault; KHF, Kramer Hills fault; LF, Leuhman fault; MVF, Mirage Valley fault; SF, Spring fault. Red dots show gravity measurements made on bedrock, blue squares, gravity measurements near bedrock outcrops or bedrock constraint value; magenta triangles indicate wells that penetrated bedrock. "?" in map indicates where bedrock gravity is poorly constrained. 


\section{References Cited}

Blakely, R.J., 1995, Potential theory in gravity and magnetic applications: Cambridge, England, Cambridge University Press, 441 p., at https://doi.org/10.1017/ CBO9780511549816.

Briggs, I.C., 1974, Machine contouring using minimum curvature: Geophysics, v. 39, no. 1, p. 39-48., at https://doi.org/ 10.1190/1.1440410.

Brocher, T.M., 2005, Empirical relations between elastic wavespeeds and density in the Earth's crust: Bulletin of the Seismological Society of America, v. 95, no. 6, p. 2081-2092, at https://doi.org/10.1785/0120050077.

Dibblee, T.W., Jr., 1960a, Geologic map of the Hawes quadrangle, San Bernardino County, California: U.S. Geological Survey Mineral Investigations Field Studies Map MF-226, scale $1: 62,500$.

Dibblee, T.W., Jr., 1960b, Geology of the Rogers Lake and Kramer quadrangles, California: U.S. Geological Survey Bulletin 1089-B, 139 p.

Dibblee, T.W., Jr., 1967, Areal geology of the western Mojave Desert, California: U.S. Geological Survey Professional Paper 522, 153 p., at https://doi.org/10.3133/pp522.

Dixon, G.L., Ward, A.W., and Jachens, R.C., 1994, Geologic setting of East Antelope basin, with emphasis on fissuring on Rogers Lake, Edwards Air Force Base, Mojave Desert, California in Prince, K.R., Galloway, D.L., and Leake, S.A., eds., U.S. Geological Survey subsidence interest group conference, Edwards Air Force Base, Antelope Valley, California, November 18-19, 1992: U.S. Geological Survey Open-File Report 94-532, p. 35-37.

Gardner, G.H.F., Gardner, L.W., and Gregory, A.R., 1974, Formation velocity and density - The diagnostic basis for stratigraphic traps: Geophysics, v. 39, no. 6, p. 770-780, at https://doi.org/10.1190/1.1440465.

International Union of Geodesy and Geophysics, 1971, Geodetic reference system 1967: International Association of Geodesy Special Publication, no. 3, 116 p.

Jachens, R.C., and Moring, B.C., 1990, Maps of the thickness of Cenozoic deposits and the isostatic residual gravity over basement for Nevada: U.S. Geological Survey Open-File Report 90-404, 15 p., 2 plates.

Jachens, R.C., Langenheim, V.E., and Christensen, A.H., 2014, Gravity analaysis for groundwater basin definitionWestern Mojave Desert, California, app. 1 in Groundwaterflow and land-subsidence model of Antelope Valley, California: U.S. Geological Survey Scientific Investigations Report 2014-5166, 136 p.
Jachens, R.C., Langenheim, V.E., and Matti, J.C., 2002, Relationship of the 1999 Hector Mine and 1992 Landers fault ruptures to offsets on Neogene faults and distribution of late Cenozoic basins in the Eastern California Shear Zone: Bulletin of the Seismological Society of America, v. 92, no. 4, p. 1592-1605, at https://doi.org/10.1785/ 0120000915 .

Londquist, C.J., Rewis, D.L., Galloway, D.L., and McCaffrey, W.F., 1993, Hydrogeology and land subsidence, Edwards Air Force Base, Antelope Valley, California, January 1989-December 1991: U.S. Geological Survey Water-Resources Investigations Report 93-4114, 74 p.

Mabey, D.R., 1960, Gravity survey of the western Mojave Desert, California: U.S. Geological Survey Professional Paper, v. 316-D, p. 51-73.

Miller, D.M., Dudash, S.L., Green, H.L., Lidke, D.J., Amoroso, L., Phelps, G.A., and Schmidt, K.S., 2007, A new Quaternary view of northern Mojave Desert tectonics suggests changing fault patterns during the late Pleistocene in Miller, D.M., and Valin, Z.C., eds., Geomorphology and tectonics at the intersection of Silurian and Death Valleys, southern California: U.S. Geological Survey Open-File Report 2007-1424, p. 157-171.

Morelli, C., 1974, The international gravity standardization net, 1971: International Association of Geodesy Special Publication, no. 4, 194 p.

Morin, R.L., Mariano, J., and Jachens, R.C., 1990, Isostatic residual gravity map of Edwards Air Force Base and vicinity, Kern, Los Angeles, and San Bernardino counties, California: U.S. Geological Survey Open-File Report 90-0664, 1 plate, scale 62,500, at https://doi.org/10.3133/ ofr90664.

Morton, R.A., Leach, M.P., Paine, J.G., and Cardoza, M.A., 1993, Monitoring beach changes using GPS surveying techniques: Journal of Coastal Research, v. 9, no. 3, p. 702-720.

OPUS-Projects Team, 2017, OPUS-Projects: National Geodetic Survey, accessed March 17, 2017, at https://www.ngs.noaa.gov/OPUS/.

Pan-American Center for Earth and Environmental Studies, 2010, Gravity database, accessed January 8, 2010, at https://research.utep.edu/Default.aspx?tabid=1523.

Plouff, D., 1977, Preliminary documentation for a FORTRAN program to compute gravity terrain corrections based on topography digitized on a geographic grid: U.S. Geological Survey Open-File Report 77-535, 45 p., at https:/doi.org/ $10.3133 /$ ofr 77535 
Powell, R.E., and Matti, J.C., 2000, Geologic map and digital database of the Cougar Buttes 7.5' Quadrangle, San Bernardino County, California: U.S. Geological Survey Open-File Report 00-175, 34 p., at https://doi.org/10.3133/ ofr00175.

Roberts, C.W., and Jachens, R.C., 1986, High-precision gravity stations for monitoring vertical crustal motion in southern California: U.S. Geological Survey Open-File Report 86-44, 76 p., at https://doi.org/10.3133/ofr8644.

Roberts, C.W., and Jachens, R.C., 1999, Preliminary aeromagnetic anomaly map of California: U.S. Geological Survey Open-File Report 99-440, 14 p.
Rydlund, P.H., Jr., and Densmore, B.K., 2012, Methods of practice and guidelines for using survey-grade global navigation satellite systems (GNSS) to establish vertical datum in the United States Geological Survey: U.S. Geological Survey Techniques and Methods, book 11, chap. D1, 102 p., at https://pubs.usgs.gov/tm/11d1/.

Subsurface Surveys, Inc., 1990, Inventory of groundwater stored in the Mojave River basins: Subsurface Surveys, Inc., Solana Beach, California, report prepared for the Mojave Water Agency, Apple Valley, California, 47 p.

Telford, W.M., Geldart, L.P., and Sheriff, R.E., 1990, Applied Geophysics 2nd ed.: New York, Cambridge University Press, 770 p., at https://doi.org/10.1017/ CBO9781139167932.
Menlo Park Publishing Service Center, California

Manuscript approved for publication November 5, 2019

Edited by Phil Frederick

Layout by Kimber Petersen 
